\title{
KAEMPFERIA JENJITTIKULIAE (KAEMPFERIA SUBG. PROTANTHIUM: ZINGIBERACEAE), A NEW, ENDANGERED SPECIES ENDEMIC TO THAILAND
}

\section{N. Nopporncharoenkul ${ }^{1}$, T. Somnoo ${ }^{2}$, W. Tanming ${ }^{2}$ \& C. Maknoi ${ }^{3}$}

\begin{abstract}
Kaempferia jenjittikuliae, a new species of Kaempferia subg. Protanthium (Zingiberaceae) from Central-Northeastern Thailand, is described and illustrated. The diagnostic characters of this novel taxon are discussed and compared with those of the morphologically similar species Kaempferia lopburiensis, $K$. rotunda and $K$. udonensis. Detailed photographs of plants and dissected flowers, and information on phenology, distribution and ecology, are provided. A preliminary IUCN conservation assessment of Critically Endangered (CR) is assigned.
\end{abstract}

Keywords. Anther crest, Critically Endangered, floral morphology, Kaempferia lopburiensis, Kaempferia rotunda, new species, Phetchabun Province.

Received 17 June 2020 Accepted 6 August 2020 Published 19 March 2021

\section{Introduction}

Kaempferia L. (Zingiberaceae) comprises approximately 40 taxa with accepted names, mainly from monsoonal tropical Asia (Linnaeus, 1753; Mabberley, 2017). Thailand, which is situated in the Indo-Burmese biodiversity hotspot, is regarded as one of the centres of distribution of the genus, with the richest species diversity (Sirirugsa, 1992; Larsen \& Larsen, 2006). Over the past 20 years, numerous descriptions of new taxa from Thailand have been published, which now hosts more than 30 native Kaempferia species (Picheansoonthon, 2010, 2011; Phokham et al., 2013; Wongsuwan et al., 2015; Nopporncharoenkul \& Jenjittikul, 2017, 2018; Saensouk \& Saensouk, 2019a, 2019b; Jenjittikul \& Ruchisansakun, 2020;

Nopporncharoenkul et al., 2020; Wongsuwan et al., 2020).

According to the position of the inflorescence, two subgenera are recognised in Kaempferia (Insisiengmay et al., 2018): subg. Kaempferia L. and subg. Protanthium (Horan.) Baker (Horaninow, 1862; Baker, 1890; Kam, 1980). The species in subg. Kaempferia typically produce inflorescences between the innermost leaves or in the pseudostems. Most of them have a short peduncle that is completely enclosed by the leaf sheaths or is sessile, although a few species display an obvious elongated peduncle, for example Kaempferia koontermii Prasarn, Wongsuwan \& Picheans. (Wongsuwan et al., 2015). In contrast, the species belonging to subg. Protanthium produce inflorescences directly from the rhizome,

${ }^{1}$ Department of Plant Science, Faculty of Science, Mahidol University, Ratchathewi, Bangkok 10400, Thailand. E-mail: nattapon.noppornch@gmail.com.

${ }^{2}$ Queen Sirikit Botanic Garden, The Botanical Garden Organization, Mae Rim, Chiang Mai 50180, Thailand.

${ }^{3}$ Romklao Botanic Garden, Bopak, Chattrakarn, Phitsanulok 65170, Thailand. 
usually separated from the pseudostem. The inflorescences emerge from the ground before the leafy shoot arises, giving these plants the common name dok din in Thai ('earth flower') (Nopporncharoenkul \& Jenjittikul, 2018).

Currently, 13 species are recognised in Kaempferia subg. Protanthium, namely $K$. rotunda L. (Linnaeus, 1753); K. simaoensis Y.Y.Qian (Qian, 1995; Nopporncharoenkul et al., 2016); K. grandifolia Saensouk \& Jenjitt. (Saensouk \& Jenjittikul, 2001); K. lopburiensis Picheans. (Picheansoonthon, 2010); K. udonensis Picheans. \& Phokham, K. xiengkhouangensis Picheans. \& Phokham (Phokham et al., 2013); K noctiflora Noppornch. \& Jenjitt. (Nopporncharoenkul \& Jenjittikul, 2017); K. graminifolia Noppornch. \& Jenjitt. (Nopporncharoenkul \& Jenjittikul, 2018); K. albiflora Jenjitt. \& Ruchis. (Jenjittikul \& Ruchisansakun, 2020); K. aurora Noppornch. \& Jenjitt.; K. caespitosa Noppornch. \& Jenjitt. (Nopporncharoenkul et al., 2020); K. kamolwaniae Picheans., Meechonk. \& Wongsuwan (Wongsuwan et al., 2020); and K. takensis Boonma \& Saensouk (Boonma et al., 2020). One of these, Kaempferia xiengkhouangensis, is a species endemic to Laos; the other taxa have been found in Thailand (Sirirugsa, 1992; Larsen \& Larsen, 2006; Phokham et al., 2013; Boonma et al., 2020; Nopporncharoenkul et al., 2020).

Taxonomically, two main types of floral plane, namely perpendicular and parallel to the ground, have been used as effective characteristics for distinguishing the species in Kaempferia subg. Protanthium (Nopporncharoenkul et al., 2020). The perpendicular type of floral plane is characterised by upright to slightly arcuate lateral staminodes and a deflexed distal half labellum; it is generally found in K. aurora, K. graminifolia, K. kamolwaniae, K. noctiflora, $K$. rotunda and $K$. simaoensis (Nopporncharoenkul et al., 2020; Wongsuwan et al., 2020). The parallel floral plane is characterised by a T shape formed by the horizontal staminodes and labellum, which are arranged in the same plane and parallel to the ground. The species with this latter type of floral plane are K. albiflora, K. caespitosa, K. grandifolia, K. lopburiensis, K. takensis, K. udonensis and K. xiengkhouangensis (Boonma et al., 2020; Nopporncharoenkul et al., 2020).

The new taxon that we describe here, Kaempferia jenjittikuliae, is a strict endemic of limestone in the Phetchabun Province of Central-Northeastern Thailand. It has very large adpressed leaves like those of Kaempferia lopburiensis and $K$. udonensis, but the flower is of the perpendicular floral plane type. We have carried out an intensive morphological study of living material from the type locality, in both flowering and vegetative phases, including comparison with protologues and herbarium specimens deposited at the main herbaria in Thailand, and found that these characters do not co-occur in any known species of Kaempferia subg. Protanthium. It is therefore with confidence that we taxonomically characterise and identify it as a species new to science. A preliminary conservation status of Critically Endangered (CR) is assigned, based on the IUCN Red List Categories and Criteria, version 14 (IUCN Standards and Petitions Subcommittee, 2019). The description of this novel taxon makes use of the technical terms in the Kew Plant Glossary (Beentje, 2016). The 
diagnostic characters are clearly discussed in relation to the morphologically closest taxa. Furthermore, an updated key to the species of Kaempferia subg. Protanthium is provided.

\section{Taxonomic treatment}

Kaempferia jenjittikuliae Noppornch., sp. nov.

Similar to Kaempferia lopburiensis Picheans. and K. udonensis Picheans. \& Phokham in its habit and leafy shoot, but differs by its upright to slightly arcuate lateral staminodes, deflexed distal half of the labellum, flat labellum base, and incision around half the length of the labellum (compared with horizontal staminodes and labellum, involute labellum base enclosing the anther, and incision more than two-thirds the length of the labellum in $K$. lopburiensis and $K$. udonensis). It is also similar to Kaempferia rotunda L. in its floral shape, but differs in its broadly ovate to suborbicular leaves adpressed to the ground and ovate, broadly elliptic to obdeltoid anther crest with irregular trilobed to tetralobed apex (compared with lanceolate-oblong to elliptic, upright leaves and oblong to ovate anther crest with bifid to bilobed apex, usually with 1-3 small teeth between the lobes in $K$. rotunda). - Type: Thailand, Phetchabun Province, Chon Daen District, Sap Phutsa, $270 \mathrm{~m}$ elevation, 19 v 2020, N. Nopporncharoenkul NNSB-760 (holotype QBG!, including flowers preserved in spirit as part of a single specimen; isotype BK!, including flowers preserved in spirit, BKF!, E!, SING!). Figures 1, 2, 3.

Rhizomatous herb, adpressed to the ground. Rhizome subglobose to ovoid, $1-2 \mathrm{~cm}$ long, $1-1.8 \mathrm{~cm}$ in diameter, brown externally, cream white internally; roots fascicled, tuberous with fibrous roots, $9-15 \mathrm{~cm}$ long; root tubers ovoid to fusiform, $1.5-3.5 \mathrm{~cm}$ long, $1.2-2 \mathrm{~cm}$ in diameter. Leafy shoot with 3 or 4 leaves; pseudostem buried in ground, $6-12 \mathrm{~cm}$ tall; leafless sheaths 1 or 2,5-12 cm long, green to reddish, apex acute, sparsely villous; leaf sheaths green to reddish, conspicuously longitudinally ridged, densely villous; ligule broadly triangular with rounded to obtuse apex, $1.5-3 \mathrm{~cm}$ long, opaque, reddish, sparsely villous; lamina sessile, broadly ovate to suborbicular, 18-46 × 16-40 cm, adaxially light green to dull green, sparsely villous at base of midvein, abaxially light green, pubescent, base rounded, margin entire, reddish band along the margin, apex acute to acuminate. Inflorescence lateral, emerging from rhizome, peduncle $1-2.2 \mathrm{~cm}$ long, with a few sparse hairs; fusiform to ovoid, 6-8 cm long, $1-2 \mathrm{~cm}$ in diameter, composed of up to 30 bracts each supporting a single flower; bracts broadly ovate to trullate, $2.5-6.5 \times 0.4-3 \mathrm{~cm}$ (outer bracts larger), apex acute, cream white to pale yellow, with a few sparse hairs; bracteoles linear to narrowly lanceolate, $2-2.8 \times 0.2-0.3 \mathrm{~cm}$, apex acute, hyaline, with a few sparse hairs. Flowers $8-10(-12.2) \mathrm{cm}$ long; floral plane perpendicular, with lateral staminodes upright to slightly arcuate and deflexed distal half of the labellum; calyx $5-5.5 \mathrm{~cm}$ long, $0.8-1 \mathrm{~cm}$ in diameter, with unilateral incision $1.2-1.4 \mathrm{~cm}$ long from apex, apex bilobed with two small teeth between lobes, hyaline, semi-translucent white, almost glabrous, but with a few villous hairs at apex; 


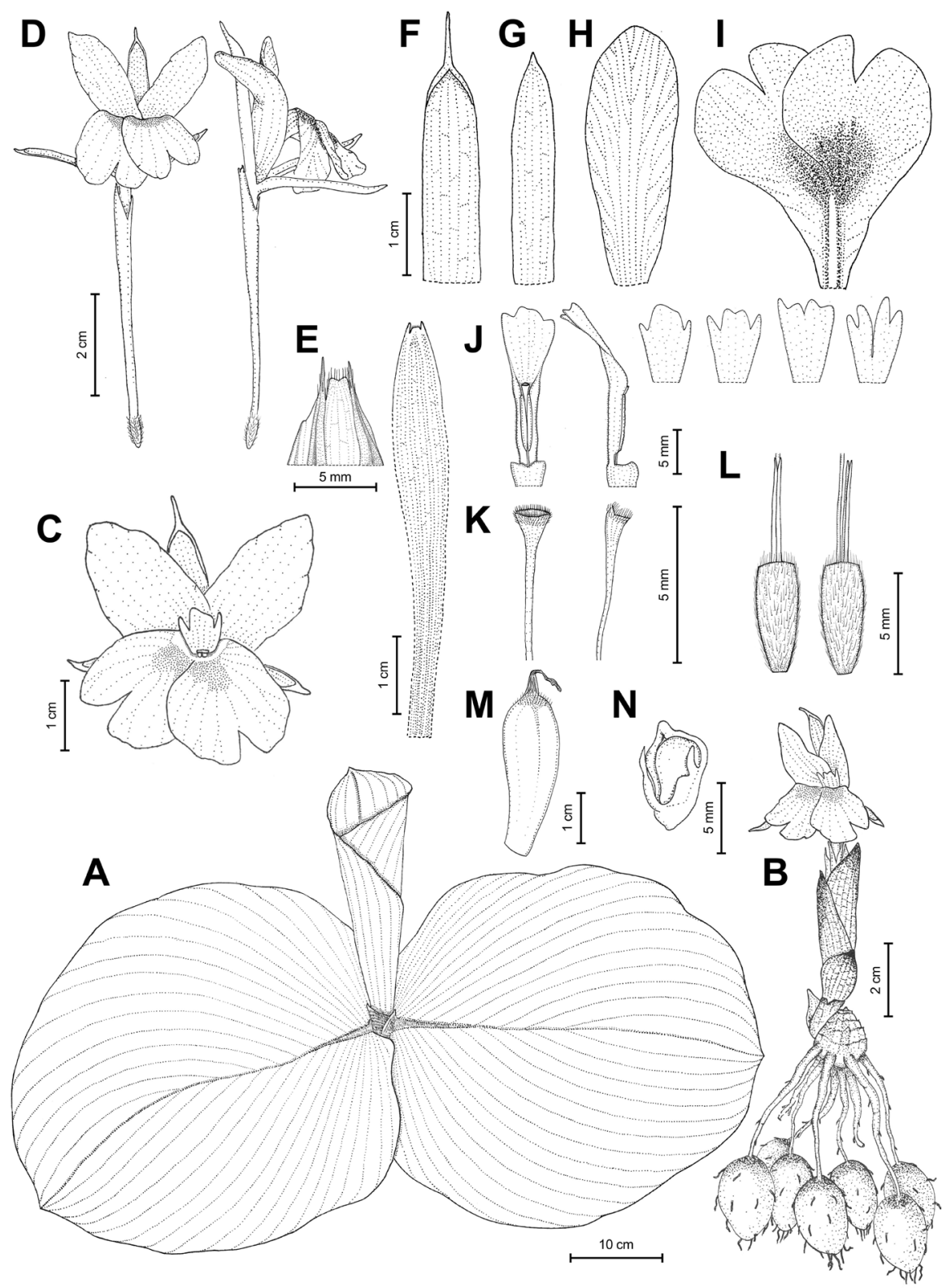

Figure 1. Kaempferia jenjittikuliae Noppornch., sp. nov. A, Habit (vegetative part); B, rhizome and inflorescence; C, flower (front view); D, flower (front and side views); E, calyx and detail of apex; $\mathrm{F}$, dorsal corolla lobe; $\mathrm{G}$, lateral corolla lobe; $\mathrm{H}$, lateral staminode; I, labellum; J, detail of stamen (front and side views) and four apices of anther crest, showing variation in shape; $\mathrm{K}$, detail of stigma with upper part of style (front and side views); L, ovary with epigynous glands and lower part of style (front and side views); $M$, fruit; $N$, seed with laciniate aril. Drawn from the holotype, accession $N$. Nopporncharoenkul NNSB-760 (QBG), by N. Nopporncharoenkul. 


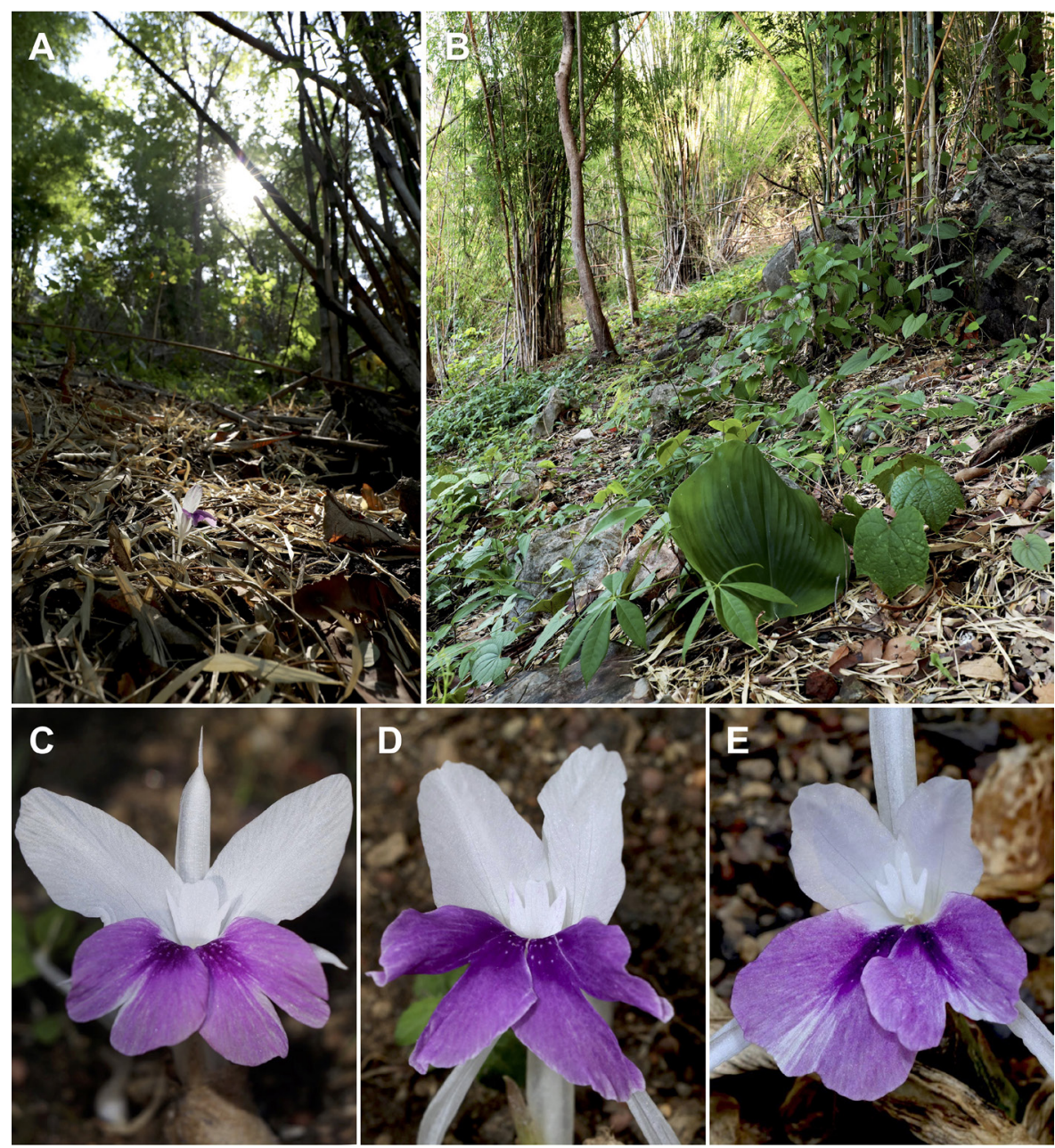

Figure 2. Kaempferia jenjittikuliae Noppornch., sp. nov. A and B, Plants in habitat (type locality, Chon Daen District, Phetchabun Province, Thailand); $\mathrm{C}-\mathrm{E}$, flowers with various shapes of anther crest (accession 20130454, QBG-living collections). Photographs taken by N. Nopporncharoenkul and T. Somnoo.

floral tube $4.5-6 \mathrm{~cm}$ long, $0.2-0.3 \mathrm{~cm}$ in diameter, narrowly cylindrical at base above ovary, narrowly funnel-shaped distally, white, glabrous; dorsal corolla lobe elliptical to ellipticoblong, 3-3.5(-5.7) × 0.6-0.8(-1) cm, apex hooded, mucronate, mucro 5-6(-10) mm long, concave, white, glabrous; lateral corolla lobes elliptic-oblong to oblong, $2.5-3(-5) \times$ $0.4-0.5(-0.7) \mathrm{cm}$, apex mucronate, mucro c. $1 \mathrm{~mm}$ long, concave, white, glabrous; lateral staminodes elliptic-oblong to obovate, $2.8-3.5(-4.6) \times 1-1.4 \mathrm{~cm}$, apex rounded, obtuse to acute, white, sometimes with purple at the apex; labellum broadly obovate to obdeltoid, $2.6-3(-4.8) \times 1.8-3(-4) \mathrm{cm}$, bilobed, with incision around half of labellum length, each lobe 

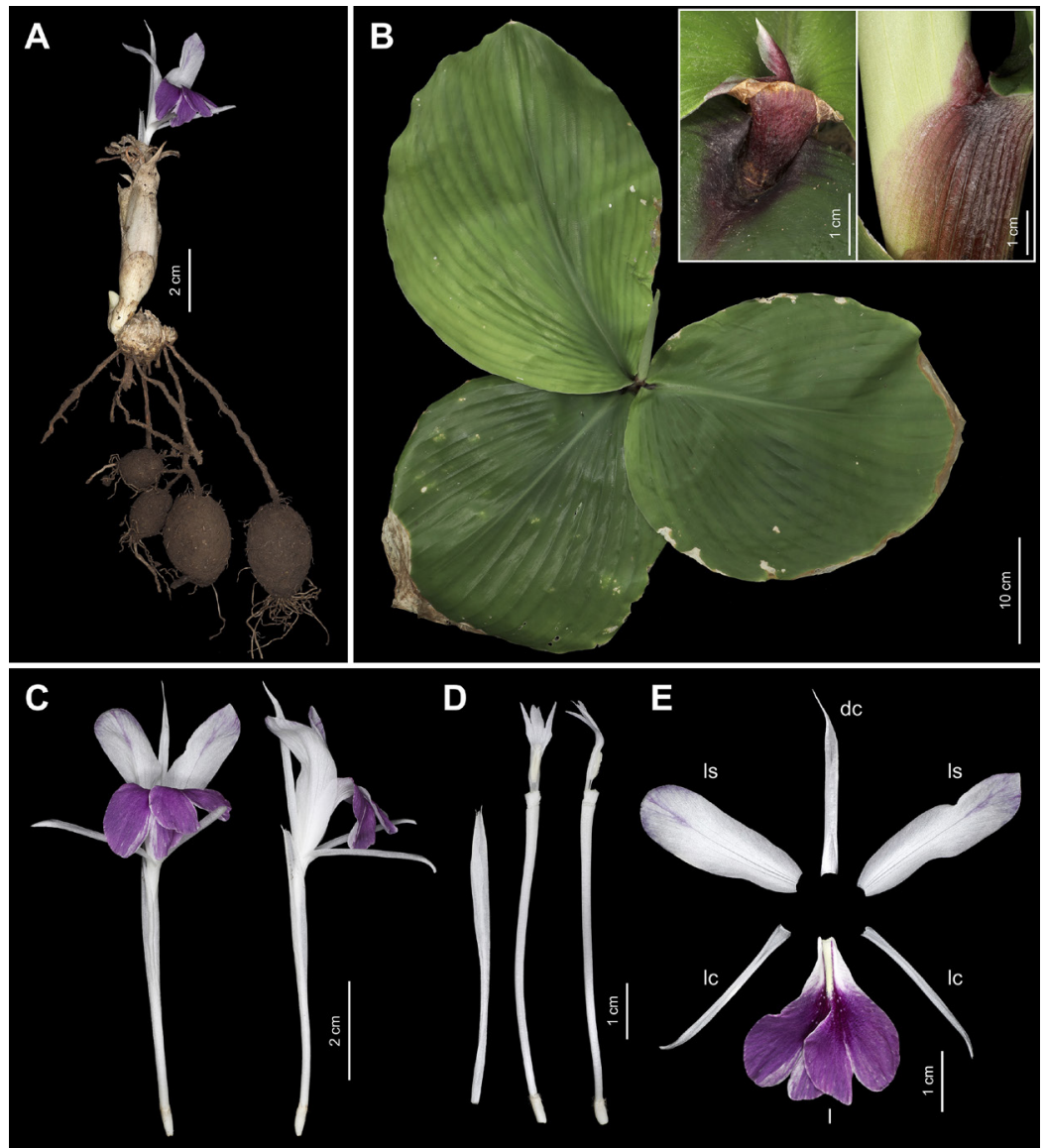

D

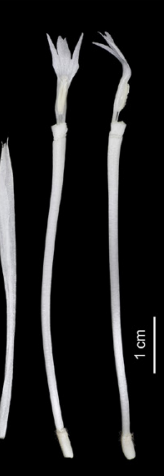

$\mathbf{E}$
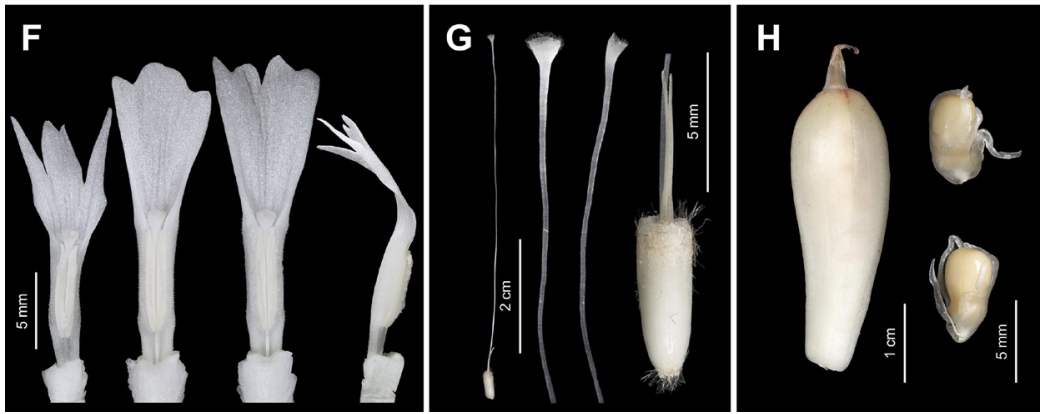

Figure 3. Kaempferia jenjittikuliae Noppornch., sp. nov. A, Inflorescence and rhizome; B, habit (inset: detail of ligule and base of midrib [left] and detail of leaf sheath [right]); C, flower (front and side views); D, calyx and floral tube with ovary and stamen (front and side views); E, flower dissection (dc, dorsal corolla lobe; I, labellum; Ic, lateral corolla lobe; Is, lateral staminode); F, detail of anther and anther crest (front and side views); G, detail of pistil (from left to right: pistil, stigma and style [front and side views], and ovary with epigynous glands); $\mathrm{H}$, fruit and seeds with a fleshy semi-translucent white, laciniate aril. Photographs of the holotype, accession N. Nopporncharoenkul NNSB-760 (QBG), taken by N. Nopporncharoenkul. 
suborbicular to broadly obovate, $1.4-1.6(-3) \times 1.2-1.6(-2) \mathrm{cm}$, apex obcordate to slightly crenate, partly overlapping, white basally with central pale yellow band surrounded by two dark purple stripes from base towards centre of lobes, purple distally including entire area of lobes; stamen 12-21 mm long; filament 1.5-2 mm long, 1.5-2 mm wide, white, puberulent with very short glandular hairs dorsally and laterally; anther 10-17(-19) $\mathrm{mm}$ long including straightened anther crest, connective tissue white, puberulent with very short glandular hairs dorsally and laterally, anther thecae $4-5(-7) \times 1-1.5 \mathrm{~mm}$, white to cream white, dehiscing along their entire length, pollen white; anther crest ovate, broadly elliptic to obdeltoid, 6-12 $\times 4-7 \mathrm{~mm}$, apex irregularly trilobed, middle lobe wider than side lobes, middle lobe sometimes deeply divided to two small lobes (making crest appear tetralobed), apex of each lobe obtuse to acute; pistil 57-66 mm long; ovary cylindrical, 5-6 mm long, c. $2 \mathrm{~mm}$ in diameter, cream white, sparsely villous, ovules numerous, placentation axile; epigynous glands 2, subulate, $5-7.5 \mathrm{~mm}$ long, pale yellow; style $52-60 \mathrm{~mm}$ long; stigma crateriform, c. $1 \times 0.5 \mathrm{~mm}$, ostiole ciliate. Fruits obovoid to ellipsoid, $2.8-3.6 \times 1-1.2 \mathrm{~cm}$, white to creamwhite with strips of reddish to light purple spots from apex towards ridges, sparsely villous at apex, with 15-24(-32) seeds; seeds subglobose, obovoid to ellipsoid, 3-5 $\times 2-3 \mathrm{~mm}$, cream-white to light brown, enclosed in a fleshy semi-translucent white, laciniate aril.

Distribution. Kaempferia jenjittikuliae is strictly endemic to the limestone area of Chon Daen District, Phetchabun Province, Central-Northeastern Thailand.

Ecology. It grows in fine loam soil with rocks under semi-shaded mixed deciduous forest with bamboo, close to the foothills at $250-270 \mathrm{~m}$ a.s.l.

Phenology. Flowering starts at the beginning of the rainy season (April) and lasts until mid-May. Fruit and seeds mature in late May. Leafy shoots usually emerge in mid-May. The plants enter dormancy in November.

Provisional IUCN Red List category. This endemic species is known only from the type locality in Chon Daen District, Phetchabun Province. The area of occupancy (AOO) is estimated to be less than $4 \mathrm{~km}^{2}$, where it occurs as two small subpopulations with few mature individuals (fewer than 300 plants). Currently, the suitable habitats, especially the limestone area in Phetchabun and adjacent provinces in Central Thailand, are severely fragmented geographically and continue to decline in area due to quarrying for the construction industry (limestone and cement materials) and urban development. Moreover, the type locality is not under any legal protection and the population is at the edge of a forest and a cassava plantation. It is likely to be directly threatened by expansion of agriculture contributing to the deterioration of the population. The current information on the AOO and population size leads us to provisionally propose that Kaempferia jenjittikuliae be treated as Critically Endangered (CR B1ab (i, ii, iii, iv) + B2ab (i, ii, iii, iv)), in accordance with the IUCN Red List Categories and Criteria, version 14 (IUCN Standards and Petitions Subcommittee, 2019). 
Etymology. The specific epithet, jenjittikuliae, is designated in honour of Dr Thaya Jenjittikul, a ginger specialist at the Department of Plant Science, Faculty of Science, Mahidol University, who has been working on Thai Zingiberaceae, especially the genus Kaempferia, for over 20 years.

Vernacular name. We propose the Thai name dok din Thaya (dok din = flower that occurs on the ground, Thaya = the first name of Dr Thaya Jenjittikul).

Specimens examined. THAILAND. Phetchabun: Chon Daen, Sap Phutsa, $250 \mathrm{~m}$ elevation, 23 vi 2013, 20130454 (living collections of Queen Sirikit Botanic Garden, Chiang Mai); ibid., $270 \mathrm{~m}$ elevation, $19 \mathrm{v}$ 2020, N. Nopporncharoenkul NNSB-760 (living collections of Queen Sirikit Botanic Garden, Chiang Mai).

Kaempferia jenjittikuliae has the largest adpressed foliage of any species belonging to subg. Protanthium. It is closely similar to Kaempferia lopburiensis and $K$. udonensis morphologically. They share the huge size of the broadly ovate to suborbicular leaves lying flat on the ground (Figure 4). These three species can be easily distinguished, however, by their floral planes as well as by differences in the position of the lateral staminodes and labellum. Kaempferia jenjittikuliae has a perpendicular floral plane with upright to slightly arcuate staminodes and a deflexed distal half labellum; in contrast, the lateral staminodes and labellum of $K$. lopburiensis and $K$. udonensis are horizontal, arranged in the same plane, and usually parallel to the ground (Table, see Figure 4B,E). In its floral shape, Kaempferia

Table. Diagnostic characters of Kaempferia jenjittikuliae and closely related taxa

\begin{tabular}{|c|c|c|c|c|}
\hline Character & K. jenjittikuliae & K. lopburiensis & K. rotunda & K. udonensis \\
\hline Leafy shoot & $\begin{array}{l}\text { Adpressed to the } \\
\text { ground }\end{array}$ & $\begin{array}{l}\text { Adpressed to the } \\
\text { ground }\end{array}$ & $\begin{array}{l}\text { Upright leaves, } \\
13-60(-78) \mathrm{cm} \text { tall }\end{array}$ & $\begin{array}{l}\text { Adpressed to the } \\
\text { ground }\end{array}$ \\
\hline Leaf sheath & $\begin{array}{l}\text { Conspicuously } \\
\text { longitudinally ridged, } \\
\text { hairy }\end{array}$ & Smooth, hairy & Smooth, usually hairy & Smooth, hairy \\
\hline Leaf shape & $\begin{array}{l}\text { Broadly ovate to } \\
\text { suborbicular, } 18-46 \times \\
16-40 \mathrm{~cm}\end{array}$ & $\begin{array}{l}\text { Suborbicular to } \\
\text { orbicular, } 19-40 \times \\
18-38 \mathrm{~cm}\end{array}$ & $\begin{array}{l}\text { Lanceolate-oblong to } \\
\text { elliptic, } 16-48(-60) \times \\
5-20 \mathrm{~cm}\end{array}$ & $\begin{array}{l}\text { Broadly ovate to } \\
\text { suborbicular, } 19-48 \times \\
18-40 \mathrm{~cm}\end{array}$ \\
\hline Floral plane & $\begin{array}{l}\text { Perpendicular to the } \\
\text { ground: staminodes } \\
\text { upright to slightly } \\
\text { arcuate and labellum } \\
\text { deflexed distal half }\end{array}$ & $\begin{array}{l}\text { Parallel to the ground: } \\
\text { lateral staminodes } \\
\text { and labellum } \\
\text { horizontal, in one } \\
\text { plane }\end{array}$ & $\begin{array}{l}\text { Perpendicular to the } \\
\text { ground: staminodes } \\
\text { upright to slightly } \\
\text { arcuate and labellum } \\
\text { deflexed distal half }\end{array}$ & $\begin{array}{l}\text { Parallel to the ground: } \\
\text { lateral staminodes and } \\
\text { labellum horizontal, in } \\
\text { one plane }\end{array}$ \\
\hline $\begin{array}{l}\text { Labellum } \\
\text { base }\end{array}$ & Flat & $\begin{array}{l}\text { Involute, enclosing the } \\
\text { anther }\end{array}$ & Flat & $\begin{array}{l}\text { Involute, enclosing the } \\
\text { anther }\end{array}$ \\
\hline Incision & $\begin{array}{l}\text { Around half of } \\
\text { labellum length }\end{array}$ & $\begin{array}{l}\text { More than two-thirds } \\
\text { of labellum length }\end{array}$ & $\begin{array}{l}\text { Around half of } \\
\text { labellum length }\end{array}$ & $\begin{array}{l}\text { More than two-thirds } \\
\text { of labellum length }\end{array}$ \\
\hline $\begin{array}{l}\text { Anther crest } \\
\text { shape }\end{array}$ & $\begin{array}{l}\text { Ovate, broadly elliptic } \\
\text { to obdeltoid }\end{array}$ & $\begin{array}{l}\text { Broadly ovate, obovate } \\
\text { to obdeltoid }\end{array}$ & Oblong to ovate & $\begin{array}{l}\text { Broadly ovate, obovate } \\
\text { to obdeltoid }\end{array}$ \\
\hline $\begin{array}{l}\text { Anther crest } \\
\text { apex }\end{array}$ & $\begin{array}{l}\text { Irregular trilobed } \\
\text { (middle lobe wider } \\
\text { than side lobes) to } \\
\text { tetralobed }\end{array}$ & $\begin{array}{l}\text { Crenate, irregular } \\
\text { trilobed to deeply } \\
\text { multilobed-crenate }\end{array}$ & $\begin{array}{l}\text { Bifid to bilobed, } \\
\text { usually with } 1-3 \text { small } \\
\text { teeth between lobes }\end{array}$ & Crenate to undulate \\
\hline
\end{tabular}



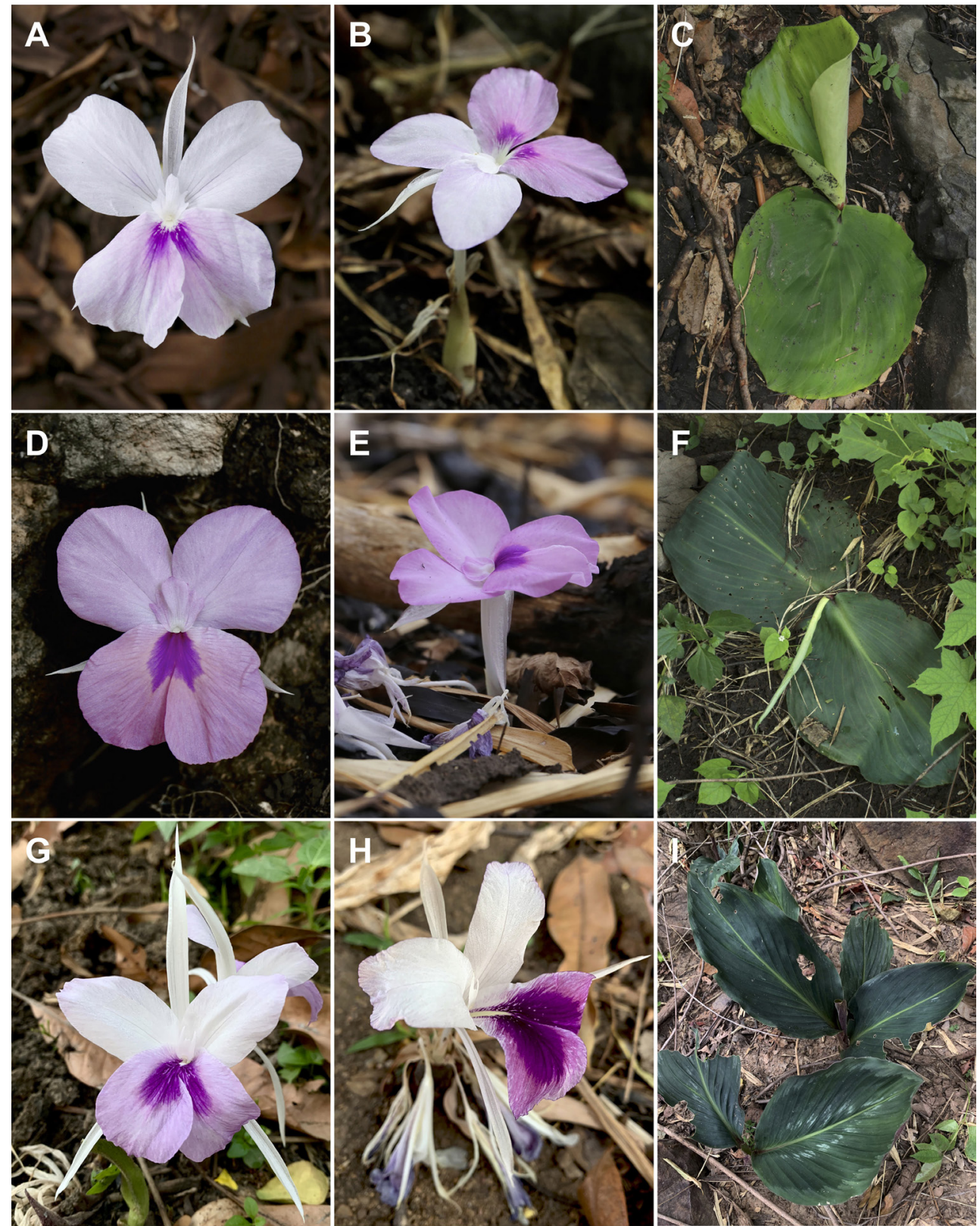

Figure 4. A-C, Kaempferia lopburiensis (accession N. Nopporncharoenkul NNSB-541, type locality, Amphoe Mueang, Lopburi Province): A, flower (front view); B, flower (side view); C, habit. D-F, K. udonensis (accession N. Nopporncharoenkul NNSB-508, Sai Yok, Kanchanaburi Province): D, flower (front view); E, flower (side view); F, habit. G-I, Kaempferia rotunda (accession N. Nopporncharoenkul NNSB-660, Wang Thong, Phitsanulok Province): G, flower (front view); $\mathrm{H}$, flower (side view); I, habit. Photographs taken by N. Nopporncharoenkul. 
jenjittikuliae also resembles $K$. rotunda, but the differences in habit and the shape of the lamina distinguish the two species fairly clearly. The large adpressed leaves of Kaempferia jenjittikuliae differ obviously from the upright leaves of $K$. rotunda (see Table, Figure 4). During our observations in the type locality, we found good fruit set with numerous viable seeds at the end of the flowering season. This evidence indicates that Kaempferia jenjittikuliae has high fertility and sexual productivity in its natural habitat.

\section{Key to the species of Kaempferia subg. Protanthium}

1a. Nyctanthous

1b. Hemeranthous 4

2a. Leaves obovate to suborbicular; ligule bilobed, c. $1 \mathrm{~cm}$ long K. grandifolia

2b. Leaves ovate, elliptic to lanceolate; ligule bilobed-truncate, 1-3 mm long 3

3a. Leaves ovate to broadly elliptic, green to deep purplish red, usually with a deep purplish red patch towards the midvein; lateral staminodes upright to slightly arcuate; labellum deflexed distal half with incision around half of its length; labellum base flat

K. noctiflora

3b. Leaves elliptic, lanceolate-oblong to narrowly lanceolate, green; lateral staminodes and labellum horizontal, arranged in the same plane; labellum with incision up to two-thirds of its length; labellum base involute, enclosing the anther K. albiflora

4a. Floral plane perpendicular to the ground; staminodes upright to slightly arcuate; labellum deflexed distal half with incision around half of its length 5

4b. Floral plane parallel to the ground; lateral staminodes and labellum horizontal, arranged in the same plane; labellum with incision more than two-thirds of its length 10

5a. Leaves adpressed to the ground, broadly ovate to suborbicular K. jenjittikuliae

5b. Leaves upright; linear, narrowly lanceolate, lanceolate-oblong, elliptic to ovate 6

6a. Leaves linear grass-like to narrowly lanceolate-oblong, less than $5 \mathrm{~cm}$ wide K. graminifolia

6b. Leaves lanceolate-oblong, elliptic to ovate, more than $5 \mathrm{~cm}$ wide 7

7a. Labellum with two conspicuous yellow bands from base towards sinus; anther crest obtuse to trilobed-undulate, the middle lobe more elongated than side lobes

K. simaoensis

7b. Labellum with a white or pale yellow band from base towards sinus, usually surrounded by purple stripes; anther crest bilobed to tridentate 8

8a. Anther crest tridentate; epigynous gland 8-12 mm long; colour of wilted staminodes and labellum brownish orange K. aurora 
8b. Anther crest bilobed, usually with 1-3 small teeth or lobes between the main lobes; epigynous gland 2-6 mm long; colour of wilted staminodes and labellum white with deep purple to blue 9

9a. Leaves petiolate; ligule less than $5 \mathrm{~mm}$ long K. rotunda

9b. Leaves sessile; ligule 6-9 $\mathrm{mm}$ long K. kamolwaniae

10a. Leaves upright, oblong, elliptic to ovate 11

10b. Leaves adpressed to the ground, broadly ovate, suborbicular to orbicular 13

11a. Lateral staminodes pure white; labellum white with a pale yellow patch from base towards sinus K. caespitosa

11b. Lateral staminodes light pink to purple; labellum light pink to purple with two large darker pink to deep purple spots at sinus 12

12a. Leaves sessile, green K. xiengkhouangensis

12b. Leaves petiolate, green usually with 1-3 layers of white to pale light green variegation

K. takensis

13a. Labellum with a white patch from base towards sinus K. lopburiensis 13b. Labellum without a white patch from base towards sinus K. udonensis

\section{Acknowledgements}

The first author would like to express gratitude to Dr Thaya Jenjittikul, who encouraged him to study the systematics and species diversity of Kaempferia subg. Protanthium. We are grateful to Dr Piyakaset Suksathan from Queen Sirikit Botanic Garden for access to living collections in the Zingiberaceae nursery at QSBG, Chiang Mai, Thailand, and Dr Supaporn Rodpradit for providing valuable information on this novel taxon. We would like to thank Mrs Darat Tanomaied for her assistance during our fieldwork. We thank Dr Mark Newman and Dr Jana Leong-Škorničková for their constructive suggestions and discussion contributing to improvements in the manuscript. The authors gratefully acknowledge the directors and curators of BK, BKF, QBG, SING, and Suan Luang Rama IX herbaria for specimen assessments.

\section{References}

Baker JG. 1890. Kaempferia L. In: Hooker JD, editor. The Flora of British India, vol. 6. London: L. Reeve \& Co. https://doi.org/10.5962/bhl.title.678. pp. 218-224.

Beentje H. 2016. The Kew Plant Glossary: An Illustrated Dictionary of Plant Terms, 2nd edition. Richmond: Royal Botanic Gardens, Kew.

Boonma T, Saensouk S, Saensouk P. 2020. Two new species of Kaempferia L. (Zingiberaceae) from Thailand. Taiwania. 65(3):371-381. https://doi.org/10.6165/tai.2020.65.371 
Horaninow P. 1862. Kaempferia. In: Horaninow P, editor. Prodromus Monographiae Scitaminearum: Additis Nonnullis de Phytographia, de Monocotyleis et Orchideis. Saint Petersburg: Petropoli. https://doi.org/10.5962/bhl.title.44562. p. 21.

Insisiengmay O, Newman M, Haevermans T. 2018. (2581) Proposal to conserve the name Kaempferia rotunda (Zingiberaceae) with a conserved type. Taxon. 67(1):207-208. https://doi. org/10.12705/671.19

IUCN Standards and Petitions Subcommittee. 2019. Guidelines for Using the IUCN Red List Categories and Criteria, version 14. http://www.iucnredlist.org/documents/RedListGuidelines.pdf [Accessed 20 May 2020.]

Jenjittikul T, Ruchisansakun S. 2020. Kaempferia albiflora (Zingiberaceae), a new species from Thailand. Kew Bulletin. 75(1):13. https://doi.org/10.1007/S12225-020-9868-4

Kam YK. 1980. Taxonomic studies in the genus Kaempferia (Zingiberaceae). Notes from the Royal Botanic Garden Edinburgh. 38:1-12.

Larsen K, Larsen S. 2006. The Gingers of Thailand: Kaempferia L. In: Larsen K, Larsen S, editors. Gingers of Thailand. Chiang Mai: Queen Sirikit Botanic Garden. pp. 55-61.

Linnaeus C. 1753. Species plantarum, exhibentes plantas rite cognitas, ad genera relatas, cum differentiis specificis, nominibus trivialibus, synonymis selectis, locis natalibus, secundum systema sexuale digestas. Holmiae: Laurentii Salvii [Stockholm: Laurentius Salvius]. https://doi.org/10.5962/ bhl.title.669

Mabberley DJ. 2017. Mabberley's Plant-book: A Portable Dictionary of Plants, their Classification and Uses, 4th edition. Cambridge: Cambridge University Press. https://doi.org/10.1017/9781316335581

Nopporncharoenkul N, Jenjittikul T. 2017. Kaempferia noctiflora (Zingiberaceae), a new species from Northern Thailand. Phytotaxa. 316(1):67-72. https://doi.org/10.11646/phytotaxa.316.1.6

Nopporncharoenkul N, Jenjittikul T. 2018. Kaempferia graminifolia (subgen. Protanthium:

Zingiberaceae), a new endemic species from Thailand. Phytotaxa. 379(3):261-266. https://doi. org/10.11646/phytotaxa.379.3.4

Nopporncharoenkul N, Soontornchainaksaeng P, Jenjittikul T, Chuenboonngarm N, Viboonjun U. 2016. Kaempferia simaoensis (Zingiberaceae), a new record for Thailand: evidence from nuclear ITS2 sequence analyses. Thai Journal of Botany. 8:81-91.

Nopporncharoenkul N, Laongsri W, Jenjittikul T. 2020. Two new species of Kaempferia subgenus Protanthium (Zingiberaceae) from northern Thailand. Nordic Journal of Botany. 38(2):e02633. https://doi.org/10.1111/njb.02633

Phokham B, Wongsuwan P, Picheansoonthon C. 2013. Three new species of Kaempferia

(Zingiberaceae) from Thailand and Laos. Journal of Japanese Botany. 88(5):297-308.

Picheansoonthon C. 2010. Kaempferia lopburiensis (Zingiberaceae), a new species from Central Thailand. Journal of Japanese Botany. 85(3):148-152.

Picheansoonthon C. 2011. Two new Kaempferia (Zingiberaceae) from Thailand. Journal of Japanese Botany. 86(1):1-8.

Qian YY. 1995. Three new species of Yunnan plants. Acta Botanica Sinica. 10:65-72.

Saensouk S, Jenjittikul T. 2001. Kaempferia grandifolia sp. nov. (Zingiberaceae) a new species from 
Thailand. Nordic Journal of Botany. 21(2):139-142. https://doi.org/10.1111/j.1756-1051.2001. tb01349.x

Saensouk S, Saensouk P. 2019a. Kaempferia mahasarakhamensis, a new species from Thailand. Taiwania, 64(1):39-42. https://doi.org/10.6165/tai.2019.64.39

Saensouk S, Saensouk P. 2019b. Kaempferia phuphanensis (Zingiberaceae), a new species from Thailand. Journal of Japanese Botany. 94(3):149-152.

Sirirugsa P. 1992. Taxonomy of the genus Kaempferia (Zingiberaceae) in Thailand. Thai Forest Bulletin, Botany. 19:1-15.

Wongsuwan P, Prasarn S, Picheansoonthon C. 2015. Kaempferia koontermii (Zingiberaceae) - a new species from Thailand. Journal of Japanese Botany. 90(1):29-33.

Wongsuwan P, Meechonkit P, Phokham B, Sangnark S, Yupparach P, Picheansoonthon C. 2020. A new species of Kaempferia (Zingiberaceae) from Northern Thailand. Journal of Japanese Botany. 95(1):34-38. 